\title{
Biomass Production for Energy in India: Review
}

\author{
Rashad A. Hegazy ${ }^{1,2, *}$ \\ ${ }^{1}$ Agricultural Engineering Department, Kafrelsheikh University, Egypt \\ ${ }^{2}$ ICCR Scholarship, Dept. of Farm Power \& Machinery, PAU Ludhiana-141004, India
}

\begin{abstract}
This paper presents a general view about biomass production in India and its potential energy for use in different fields. India has tremendous potential for energy generation through biomass and its residues. Biomass energy is normally produced from firewood, agricultural residues such as bagasse, crop stalks, animal dung and wastes generated from agro-based industries. With the estimated and predicted values, the generating power from the surplus biomass in India was significant and it will continue to be more effective in future. Residue use as a fuel in India is estimated to be $216 \mathrm{Mt}$ as projected value in 2010, recently, around $605 \mathrm{MW}$ of electricity is being produced from biomass firing and $720 \mathrm{MW}$ from cogeneration activities for residue. About $185 \mathrm{Mt}(40 \%)$ of the dung collected is used as fuel in cook stoves. The potential for biogas production annually is 8750 million $\mathrm{m}^{3}$ from $251 \mathrm{Mt}$ of dung. The amount of fuel-wood consumption during year 2004 was 205 million tonnes used as fuel for traditional cook stoves with low efficiency, $16 \mathrm{Mt}$ used in industrial sector producing $10 \mathrm{PJ}$, and it was estimated that the production of fuel wood and charcoal increased to the rate of 1.98 per cent per annum. The total quantity of solid wastes generated in larger towns and cities has been estimated at $40 \mathrm{Mt}$ in 2001, and in 2005 the average MSW generation in overall India was approximately $100,000 \mathrm{Mt} /$ day. For the wastewater in India, in 2010, the energy estimated to be around $3929.8 \mathrm{TJ}$ as energy value of $\mathrm{CH} 4$.
\end{abstract}

Keywords: Biomass, energy, crop residues, animal manure, fuelwood and municipal solid wastes.

\section{INTRODUCTION}

Biomass energy accounts for about $15 \%$ of the world's primary energy consumption and about $38 \%$ of the primary energy consumption in developing countries [1]. Due to technological developments and cost reductions, renewables, especially solar, hydro, wind and biomass energy are gaining momentum. Further, renewable sources, particularly biomass, are equitably distributed and less environmentally destructive than the current fossil fuel sources [2-4]. In India, the total installed capacity from non-conventional energy (nuclear, biomass, hydro, thermal, wind) is $108613 \mathrm{MW}$, biomass has only $640 \mathrm{MW}(0.6 \%)$ [5]. Biomass often accounts for more than $90 \%$ of the total rural energy supplies in developing countries, a survey carried out in India showed that the share of biomass fuels in rural household energy consumption had declined from $97 \%$ to $94 \%$, but that of fuelwood had increased from $42 \%$ to $47 \%$ [6].

Biomass combustion provides basic energy requirements for cooking and heating of rural households and for process heat in a variety of traditional industries in the developing countries. In general, biomass energy use in such cases is characterized by low efficiency so that the biomass fuels used could potentially provide a much more extensive energy service than at present if these were

*Address correspondence to this author at the Department of Agricultural Engineering, Faculty of Agriculture, Kafrelsheikh University DAPO Box 33516, Kafrelsheikh, Egypt; Tel: +201000870898; Fax: +20479102930;

E-mail: rashad.hegazy@agr.kfs.edu.eg used efficiently [4]. In India, biomass fuels dominate the rural energy consumption patterns, accounting for over $80 \%$ of total energy consumed Fuelwood, crop residues (including plantation crops) and livestock dung are the biomass fuels used in rural areas. Fuelwood is the preferred and most dominant biomass source accounting for $54 \%$ of biofuels used in India. Improving the conversion efficiency would be a significant step towards improving the quality of life and environment. Efforts are already under way to promote efficient devices and alternate energy sources for improving the quality of life and conserving biomass resources [7], over 370 million tonnes of biomass every year are generated. In addition to the direct harvesting from plants, biomass is also produced as a byproduct in many agro based industries such as rice husk from rice mill, saw dust from saw mill, bagasse from sugar mills etc. It has been estimated that about $17 \mathrm{GW}$ of power can be generated through cogeneration, combustion and gasification routes from the available biomass. However, for this potential to be realized, data on production, present usage patterns, prices and seasonal fluctuation on biomass is essentially required [8].

Biomass energy plays a vital role in meeting local energy demand in many regions of the developing world. Biomass is a primary source of energy for close to 2.4 billion people in developing countries [9]. It is easily available to many of the world's poor and provides vital and affordable energy for cooking and space heating. Biomass-based industries are a 
significant source of enterprise development, job creation and income generation in rural areas [10-12]. Modern biomass energy is widely used in many developing countries as well as in parts of the industrialized world. With proper management backed by adherence to appropriate ecological practices, modern biomass can be a sustainable source of electricity as well as liquid and gaseous fuels. Biomass, therefore, is not only a vital source of energy for many today but is likely to remain an important source of energy in the future subject to its sustainable exploitation $[13,14]$. The biomass industry will have to improve its image, ensure it is using only sustainably produced material, and become more efficient in biomass delivery and bioenergy conversion operations and less reliant on government incentives [15]. From implementation point of view, research and development in feedstock engineering also require continued support and guidance of a number of stakeholders. The prime industries of concern here include the users of feedstock, equipment manufacturers, and farmers. Several national laboratories and universities are actively involved in specific biomass research and conversion technologies. A full integration of all these activities minimizes duplication resulting in an accelerated approach to full utilization of bioenergy resources [16].

\section{CATEGORIZATION OF BIOMASS ENERGY}

Biomass energy use can be categorized in three clusters: Traditional, Improved and Modern

I. Traditional biomass energy is a local energy source, which is readily available to meet the energy needs of a significant proportion of the population, particularly the poor in rural areas of the developing world. Traditional biomass energy is low cost and it does not require processing before use [17].

II. Improved Biomass Energy; contributes to more efficient and environmentally sound use of biomass energy. Improved cookstoves, for instance, are designed to reduce heat loss, decrease indoor air pollution, increase combustion efficiency and attain a higher heat transfer $[18,19]$.

III. Modern Biomass Energy; Modern biomass technologies have the potential to provide improved energy services based on available biomass resources and agricultural residues.
Widespread use of combined heat and power generation biomass options in rural areas can address multiple social, economic and environmental issues that now constrain local development. The availability of low cost biomass power in rural areas could help provide cleaner, more efficient energy services to support local development, promote environmental protection, provide improved domestic fuels and improve rural livelihoods. Bioenergy technologies based on sustainable biomass supply are carbon neutral and lead to net $\mathrm{CO} 2$ emission reduction if used to substitute fossil fuels [20-22]. Another advantage of modern biomass energy is its job generation potential, a very important attraction for many developing countries faced with chronic levels of unemployment or under-employment. Existing studies [11, 23] indicate that, in comparison to other primary energy sources, the job generation potential of modern biomass is among the highest.

\section{COUNTRY DETAIL}

India has a geographical area of 328.7 Mha and $2.3 \%$ of the world's forest stock [24] India's population of 966 million in 1997, 1.237 billion in 2012 and 1.4 billion by the year 2025, India's population is currently growing at $1.37 \%$, and accounts for $16 \%$ of the world's population $[25,26]$.

\section{LAND CATEGORIES}

\subsection{Crop Land}

The net sown area of India increased from 119 Mha in 1950 to 140 Mha in 1970-71, and has remained more or less stable at 142.02 till now. Cropping intensity increased from $134 \%$ in $1996-97$ to 138 percent in 2008-09 [27, 28].

\subsection{Forest Land}

The area under forests in India has remained stable, at around 64 Mha since 1980. This has been due to the effective Forest Conservation Act, 1990, which fully regulates forest conversion [24]. The afforestation programme taken up in India, which is one of the largest in the world. The area afforested in India since 1951 has been a staggering 28.38 Mha during 1950-80, the area afforested was only about 3.54 Mha. During $1980-85$, the area afforested increased significantly to about $4: 65 \mathrm{Mha}$ at the rate of $0: 95$ 
Mha/yr and peaked during 1985-90, when about 8.86 Mha was further afforested, at the rate of $1.7 \mathrm{Mh}$ a/yr. between 1990 and 1998, about 11.33 Mha has been afforested at the rate of about 1.4 Mha/yr [29].

\subsection{Broad Land}

Broad land use categories in India, other than cropland and foresting including non-agricultural area: accounts for about 22.51 Mha. This land is under settlement, buildings, road, railways, water bodies and other land uses and thus not available for agriculture; Tree crops and groves: Area under Casuarina trees, thatching grass, bamboo bushes and other tree groves which are not included under orchards, is under this category. This land category is in a degraded state; Culturable fallow: Includes lands available for cultivation but not taken up for cultivation or taken up for cultivation once but not cultivated during the current year and the last 5 years or more in succession. Such land may either be fallow or covered with shrubs; Permanent pastures and grazing land: These cover all grazing lands and meadows including village common lands and permanent pastures; Fallow land other than current fallow: All lands which were taken up for cultivation but are temporarily out of cultivation for a period of 1-5 years, and left fallow; Barren unculturable land: covers all barren and unculturable land, which cannot $b$ e brought under cultivation except at a high investment cost; and Current fallow: includes cropped areas that are Kept fallow during the current year [29].

\section{BIOMASS SOURCES}

\subsection{Agricultural Crop Residues}

In India, out of the total geographic area of 328 million hectare (Mha), the net cropped area accounts for about $43 \%$ and it appears that the net cropped area has stabilized around 140 Mha since 1970. However, the gross cropped area has increased from 152.8Mha in 1960 to about 168.6 Mha in 1996-97 and is likely to reach 178.2 Mha by 2010. In India there are two main cropping seasons, namely Kharif (based on southwest monsoon) and Rabi (north-east monsoon). Gross cropped area includes land areas subjected to multiple

Table 1: Area Under Different Crops and their Respective Residue Production in India

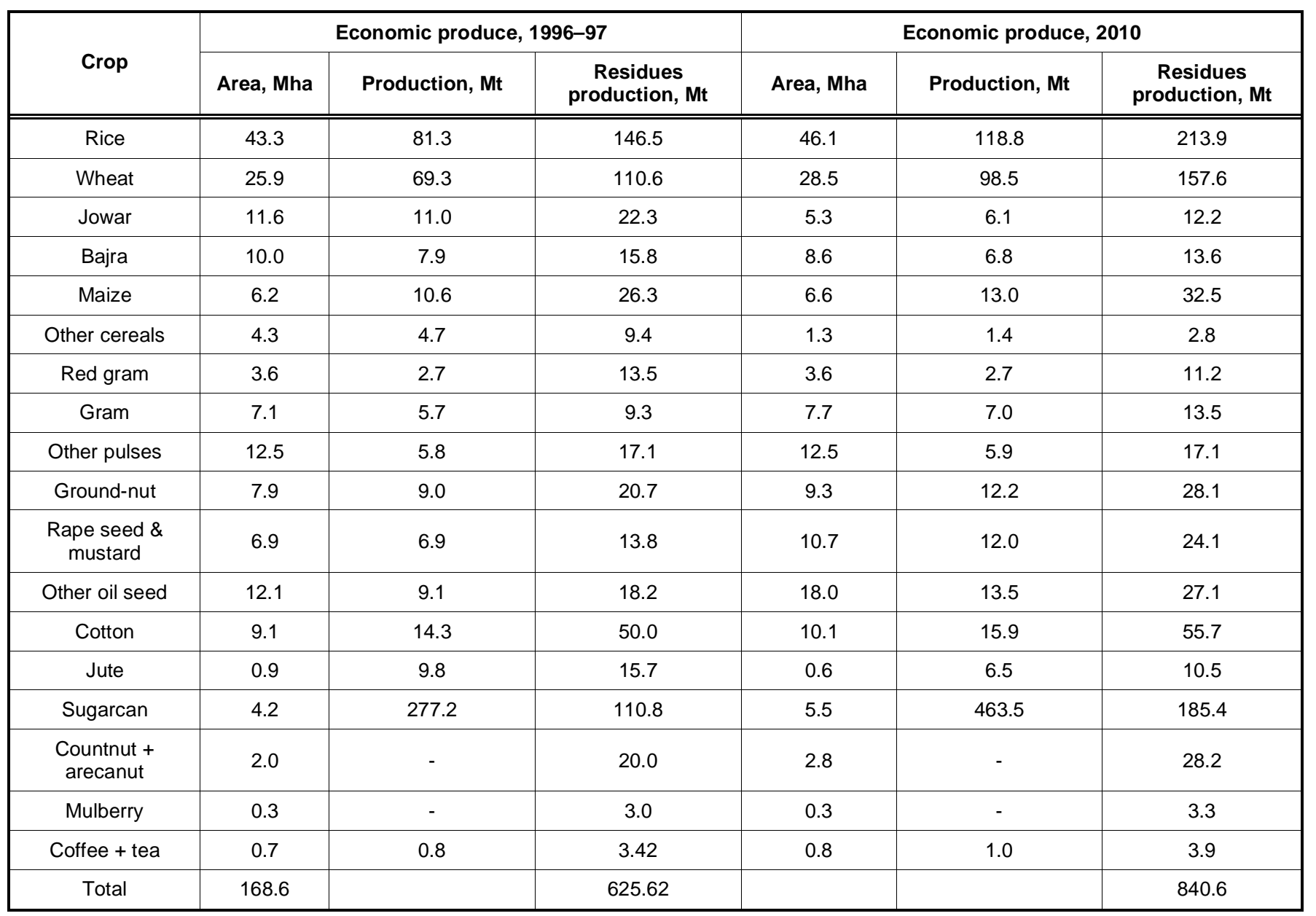


cropping (normally double cropping) in irrigated land. Net irrigated area has increased substantially from 24 Mha during 1960-61 to 55 Mha by 1996-97. Rice and wheat are the dominant crops, together accounting for $41 \%$ of cropped area, while pulses, oil seeds and other commercial crops account for $13.8 \%, 15.9 \%$ and $10.2 \%$, respectively. Cereals dominate the agricultural crops and account for $60 \%$ of cropped area, followed by pulses, cotton and sugarcane [30].

\subsubsection{Agricultural Crop Residues Production}

The knowing of distribution of crop residues help to formulate and implement renewable energy programme utilization these resources, crop residues are classified on the basis of their properties such As diameter, flexibility, density, and particle size [31]. The area under different crops and their respective residue production in 1997 and projected 2010 in India presented in Table 1 [7].

The total crop residue production in India during 1996-97 is estimated to be 626Mt of air dry weight. The dominant residues are those of rice, wheat, sugarcane and cotton accounting for $66 \%$ of the total residue production. Sugarcane and cotton residue production is 110 and $50 \mathrm{Mt}$, respectively.

\subsubsection{Current Use of Crop Residues}

The use of crop residues varies from region to region and depends on their calorific values, lignin content, density, palatability and nutritive value. Residues of most of the cereals and pulses have fodder value. However, woody nature of residues of a few crops restricts their use to fuel purpose only.

The dominant end uses of crop residues in India are as fodder for cattle, fuel for cooking and thatch material for housing. Figures $\mathbf{1}$ and $\mathbf{2}$ give the estimated total residues utilized as fodder, fuel and for other purposes in India during 1996-97 and projected 2010 respectively.

Conversion of biomass residue into useful fuel either biochemical (biogas), thermo chemical (pyrolysis and gasification) processes are now possible to resulting fuel may be solid, liquid or gas specially using residues which not used as animal feed such as paddy straw in northern states in India [32]. Crop residues, which are used as fodder, will not be available as feedstock for energy. The total potential of non-fodder crop residues available for energy is estimated to be 325 and 450 Mt for 1996-97 and 2010, respectively; another figure about biomass generated from agriculture is a measured component of the energy mix used in rural India. In 2005-06, 316.8 million tonnes of agriculture-based biomass had been generated in the country comparison to 169.8 million tonnes in 1980-81. Figure 3 shows non fodder crop residue potentially available for energy use during year 1996-97 [30, 33]. Many agricultural wastes which not used, considered have heat values greater than some well-known

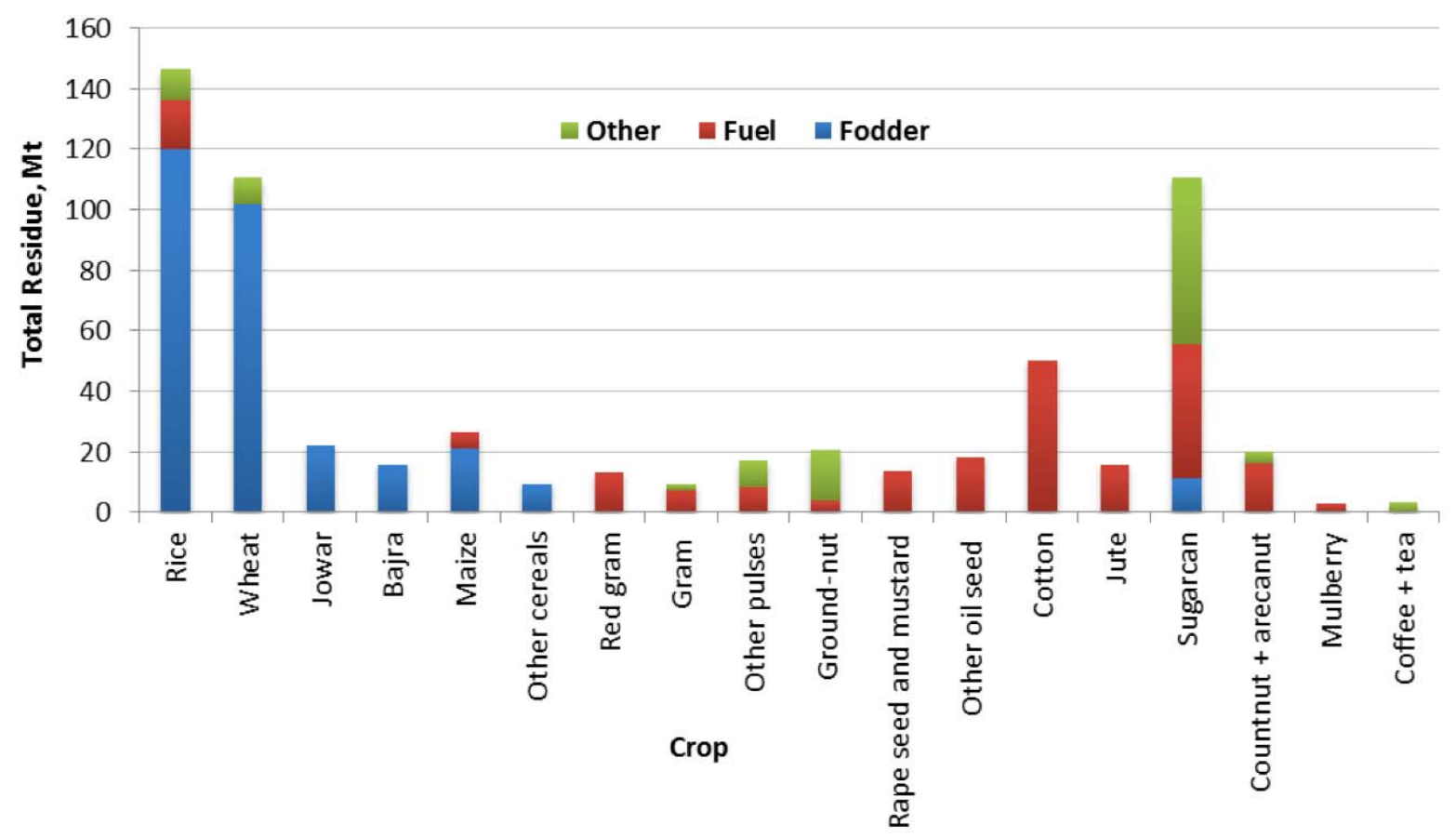

Figure 1: The estimated total residues utilized as fodder, fuel and for other purposes in India during 1996-97. 


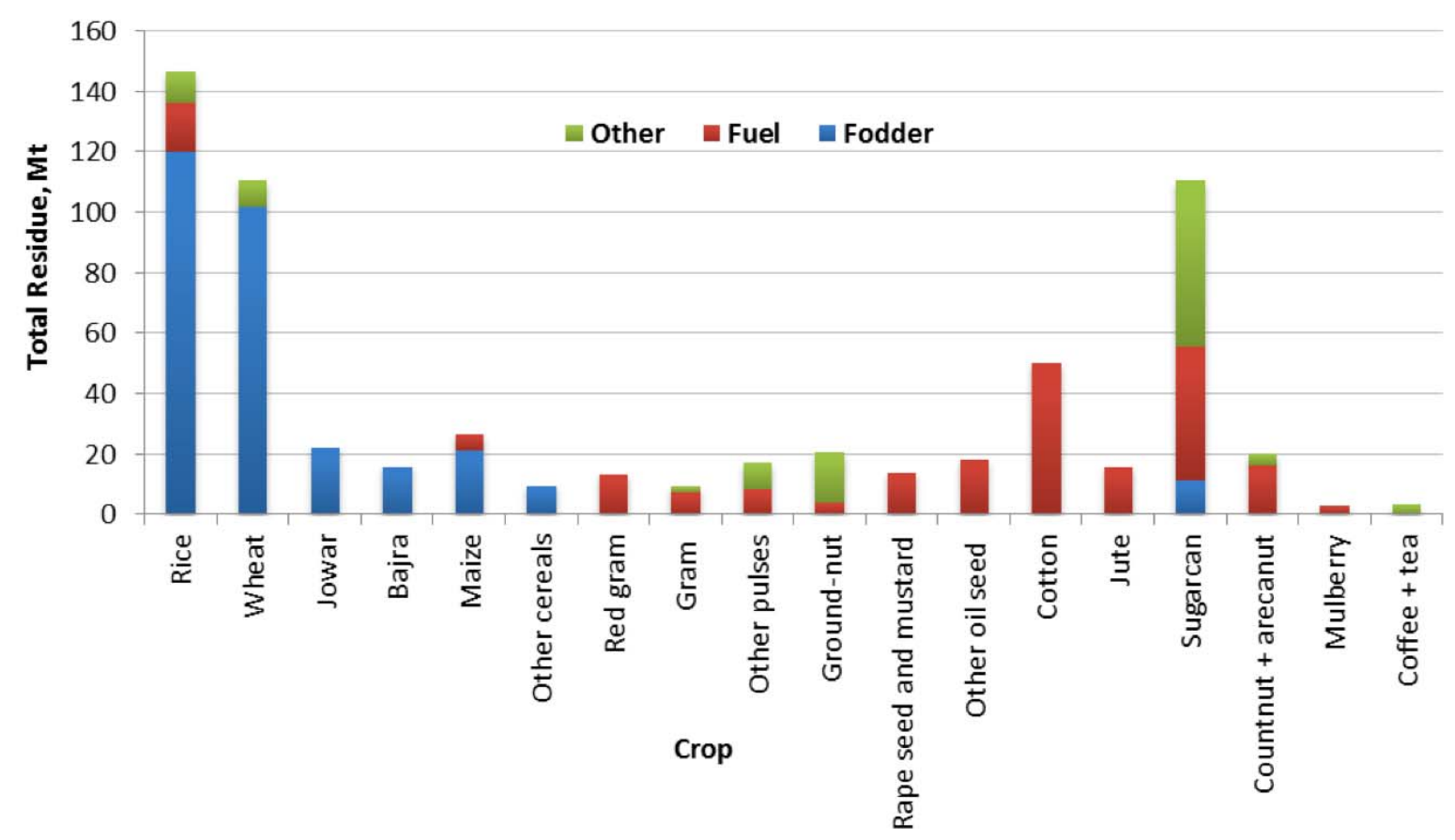

Figure 2: The estimated total residues utilized as fodder, fuel and for other purposes in India projected 2010.

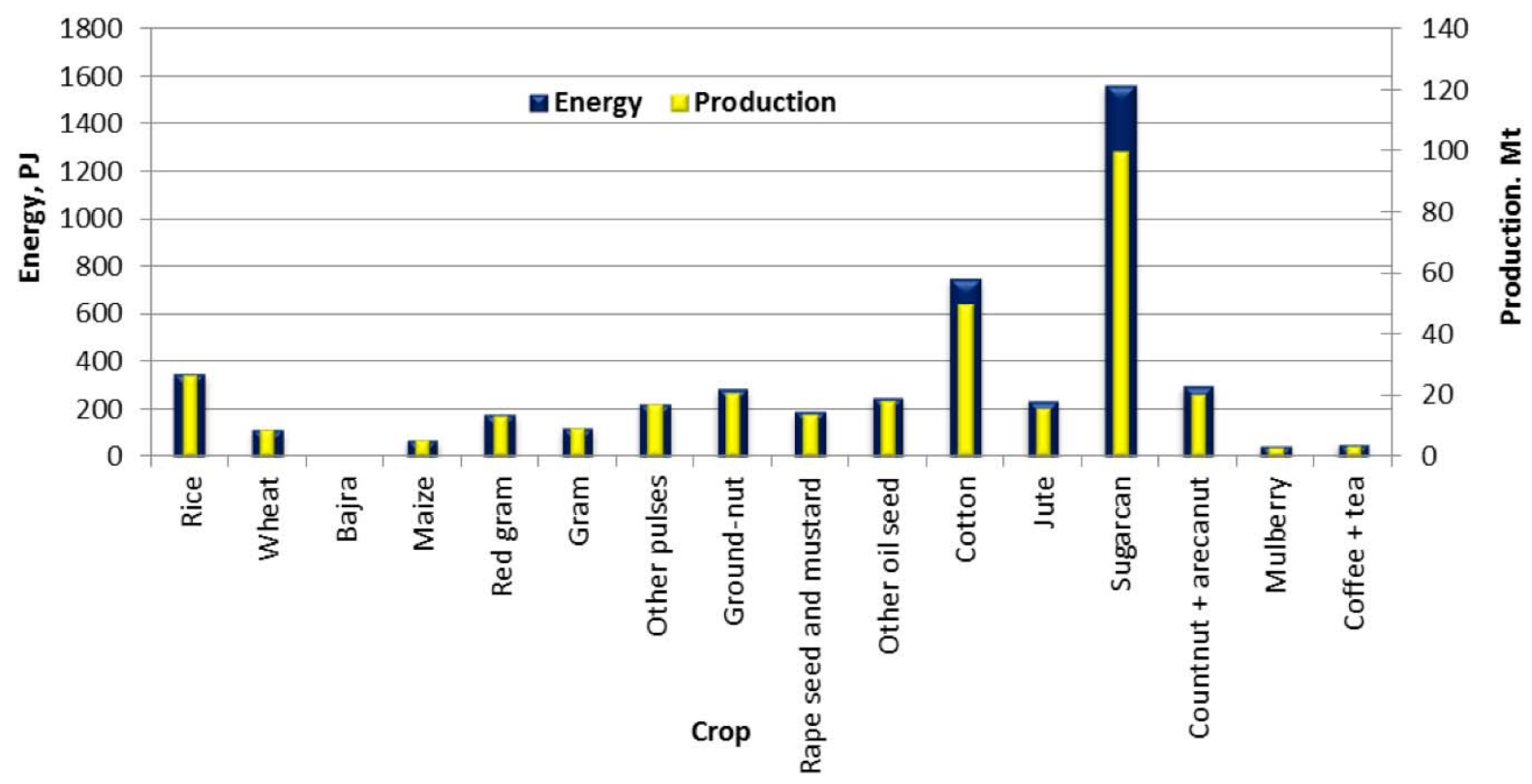

Figure 3: Non fodder crop residue potentially available for energy use during year 1996-97.

biomass-fuels and fall within the limit for the production of steam in electricity generation [34].

However, India's total installed capacity for electricity generation from biomass is $1,325 \mathrm{MW}$ and $605 \mathrm{MW}$ of electricity is being produced from biomass firing and $720 \mathrm{MW}$ from cogeneration activities. An additional $1178 \mathrm{MW}$ power is being commissioned, which will take the total power generation from biomass to $3,100 \mathrm{MW}$. Biomass as energy is gaining importance as a renewable source to strengthen the country's agriculture [35].

\subsection{Animal Manure}

India has the world's largest bovine population and recorded 294 million during 1996-97 (including cows, bullocks, buffaloes and calves), with cattle to human population ratio of 0.3 . Cattle accounts for more than 
two-thirds of the bovine population, while buffalo account for $28.6 \%$ [36].

\subsubsection{Current Dung Usage and Availability of Dung for Energy Generation}

Based on mean annual average dung yield (fresh weight) of $4.5 \mathrm{~kg} \mathrm{day}^{-1}$ for cattle and $10.2 \mathrm{~kg} \mathrm{day}^{-1} \mathrm{for}$ buffalo, total dung production is estimated to be $659 \mathrm{Mt}$ annually, with cattle dung accounting for $344 \mathrm{Mt}$ and buffalo dung accounting for $315 \mathrm{Mt}$. The corresponding dung produced from cattle and buffalo for 2010 is estimated to be 368 and $362 \mathrm{Mt}$, respectively with a total dung production of $730 \mathrm{Mt}$ [37].

About $185 \mathrm{Mt}, 40 \%$ of the dung collected is used as fuel in cook stoves. The quantity of dung used annually in the existing 2.7 million family type biogas plantsassuming 5 animals per plant is estimated to be $22 \mathrm{Mt}$. Cattle dung use for biogas has large potential for the future, as only $22 \%$ of the total potential for biogas plants is being utilized [38]. Thus, the quantity of dung unused amounts to $251 \mathrm{Mt}$. If the potential of 12 million family biogas plants, is built by 2010 at the rate of one million annually, $98.5 \mathrm{Mt}$ of dung produced could be used for biogas production. Rest of the dung is likely to be used as manure for crop production. The potential for family biogas plants in India is $12-17$ million, but only 3.65 million plants had been built by 2003 . Thus a large potential for family biogas is yet to be utilized. With the existing technology, the potential for biogas production annually is 8750 million $\mathrm{m}^{3}$ (from $251 \mathrm{Mt}$ of dung). This biogas could be used directly as cooking fuel (183 PJ) or for generation of $11.67 \mathrm{GWh}$ of electricity annually. Figure 4 presents the dung use as fuel in India in two different years 1991 and 1995 with projected value in 2010.

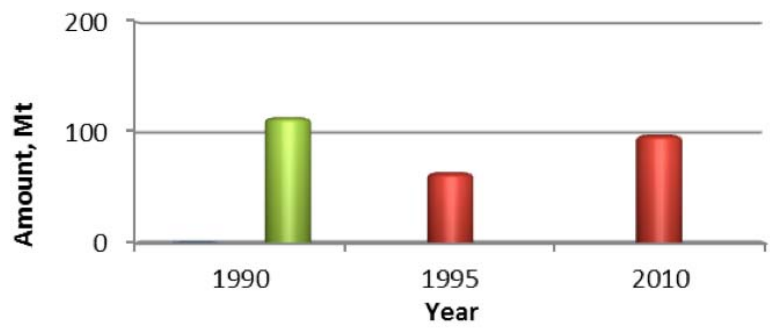

Figure 4: The dung use as fuel in India.

Recently and based on the availability of cattle dung alone from about 304 million cattle, there exists an estimated potential of about 18240 million $\mathrm{m}^{3}$ of biogas generation annually. The increasing number of poultry farms is another source and can generate biogas of 2173 million cubic meters annually with 649 million numbers of birds [39].

\subsection{Fuelwood}

One of the important features of rural energy use is the dependence on locally available biomass resources. Over 77 per cent of rural households in the country were estimated to depend on firewood and chips for cooking [40]. It has been estimated that about 2-3 million people are engaged in fuel wood 'head loading' in India, making it the largest source of employment in the energy sector in the country. It is reported that most of the fuel wood is derived from forests, with some portion also being obtained from trees growing on homesteads, farmlands, and common lands.so, Fuelwood is the dominant fuel consumed in rural India. Dependency on fuelwood has consequences, firstly on environment due to nonsustainable extraction from forests, village commons and farms and secondly, on health and quality of life of women. Many projections indicate that rural communities would continue to depend on biofuels in the future while, the scarcity of fuelwood, associated with its high price, necessitates conservation through use of efficient stoves and switch over to other fuels. Hence, in this section, the fuelwood conservation potential through shifting to efficient stoves is estimated by considering only rural households. The feasibility of different biomass conservation options is also discussed in this section. Energy required efficiency of the fuel-device combinations and fuelwood conservation potential is given in Table 2 [41].

The traditional cook stoves using fuelwood have low thermal efficiencies of about $14 \%$. Efficient stove designs with over $30 \%$ of thermal efficiency are available and are being intensively implemented in India as shown in Table 2. Field studies have shown that use of efficient stoves results in only about $20 \%$ saving of fuelwood compared with traditional stoves due to variation in cooking practices, inadequate user education, and lack of repair and improper construction of improved stoves [7]. The amount of fuel-wood consumption during year 2004 was 205 million tonnes as shown in Table 3 [42].

Total wood production (round wood) in Indian forests has increased from $199.17 \mathrm{~m}$. cum in 1970-80 to $248.52 \mathrm{~m} . \mathrm{cu} \mathrm{m}$ in 1981-2000, registering a compound growth rate of 2.03 per cent for the time period 1970-2000 (Table 2). The production of fuel wood and charcoal increased at the rate of 1.98 per cent per annum [43]. 
Table 2: Energy Required and Efficiency of Device with Fuelwood Conservation Potential

\begin{tabular}{|c|c|c|c|}
\hline Device & $\begin{array}{c}\text { Consumption } \\
\left(\mathbf{k g H H}^{-1} \mathbf{y r}^{-1}\right)\end{array}$ & $\begin{array}{c}\text { Thermal efficiency of device } \\
(\%)\end{array}$ & $\begin{array}{c}\text { Fuelwood conservation potential } \\
\left(\mathbf{k g H H}^{-1} \mathbf{\mathbf { y r } ^ { - 1 } )}\right.\end{array}$ \\
\hline \hline Traditional cookstove & 1800 & 14 & - \\
\hline Efficient cookstove & 1440 & 33 & 360 \\
\hline Kerosene stove & 159 & 60 & 1800 \\
\hline LPG & 120 & 60 & 1800 \\
\hline
\end{tabular}

Table 3: Fuel-Wood Consumption by Sector During Year 2004

\begin{tabular}{|l|c|c|}
\hline \multicolumn{1}{|c|}{ Sector } & Consumption, Million tonnes & \% of total consumption \\
\hline \hline Household & & 40.5 \\
\hline a- Forested rural & 83 & 31.7 \\
\hline b- Non forested rural & 65 & 8.3 \\
\hline c- Urban area & 17 & 80.5 \\
\hline Subtotal & 165 & 10.7 \\
\hline Cottage industry & 22 & 2 \\
\hline Rituals & 4 & 6.8 \\
\hline Restaurant, etc... & 14 & 205 \\
\hline Total & & \\
\hline
\end{tabular}

\subsection{Municipal Solid Wastes}

Generation of municipal wastes is not significant in rural areas. So, the energy potential of solid waste generated by urban population only considered. Municipal solid waste is normally collected, transported and dumped in the outskirts of towns and cities. Though sorting out for the recyclable materials by the rag pickers is common, other ways of handling, like composting, incineration, etc., also take place to some extent. The total quantity of solid wastes generated in larger towns and cities has been estimated at $20.7 \mathrm{Mt}$ annually for an urban population of 217 million in 1991 . This is increased to $40 \mathrm{Mt}$ in 2001 and expected to reach to $56 \mathrm{Mt}$ by 2010. As the urban population is increasing at a decadal growth rate of above $40 \%$, the quantity of wastes generated per family in a week has also increased substantially from $7 \mathrm{~kg}$ during 1980s to 20-30 kg at present. The data from Table 4 reveals that MSW production per capita increases with the size of the urban centre and is highest for cities with a population greater than 5 million. In India, based on 1991 census data, the estimated quantity of MSW generated in 10 major cities is more than $10 \mathrm{Mt}$ annually. Also, the average MSW generation in India is approximately $100,000 \mathrm{MT} /$ day. Out of that, only $60 \%$
$(60,000 \mathrm{MT} /$ day) is collected by municipal corporations and councils. The rest is disposed of in an unscientific manner [44]. The disposal of such huge quantities has become a major problem. Thus, the utilization of MSW for energy would mean a solution of this problem. The MSW consists of glass, metal, paper, rubber, and other combustible organic matter. The organic matter component is of relevance to energy, particularly biomethanation. Paper plus other combustible matters together account for nearly $50 \%$ of $\mathrm{MSW}$ in urban areas [36].

[45] mentioned in his study that Municipal solid waste (MSW) is the solid waste generated by households, commercial establishments, and institutions etc. The waste consists of perishable organic wastes, glass, paper, plastics, metals etc. Generally, MSW does not include construction or demolition debris or automobile scrap. Figure $\mathbf{5}$ shows the percentage of composition of MSW in Delhi city. Though details vary from city to city, MSW can be completely converted into useful fuel products. The mean energy contents in char, tar oil and pyrogas are 89.89 MJ, 151.66 MJ and 4.03MJ respectively. The char produced can provide heat for the pyrolysis reactions and could be used as fuel for domestic 
Table 4: Quantity of MSW Generated (Collected) Annually in India

\begin{tabular}{|c|c|c|c|c|}
\hline $\begin{array}{l}\text { Population range } \\
\text { (Million) }\end{array}$ & $\begin{array}{l}\text { MSW per capita } \\
\left(\text { kg capita }^{-1} \text { day }^{-1}\right)\end{array}$ & Towns & $\begin{array}{l}\text { MSW per town } \\
\text { wet wt (Kt) }\end{array}$ & $\begin{array}{c}\text { At national level } \\
\text { wet wt (Mt) }\end{array}$ \\
\hline $0.1-0.5$ & 0.21 & 372 & $33 \pm 2$ & 9.0 \\
\hline $0.5-0.1$ & 0.25 & 32 & $63 \pm 11$ & 2.0 \\
\hline $1.0-2.0$ & 0.27 & 15 & $120 \pm 24$ & 1.8 \\
\hline $2.0-5.0$ & 0.35 & 5 & $417 \pm 128$ & 2.1 \\
\hline$>5$ & 0.50 & 5 & $1729 \pm 499$ & 8.6 \\
\hline TOTAL & & 329 & & 23.5 \\
\hline
\end{tabular}

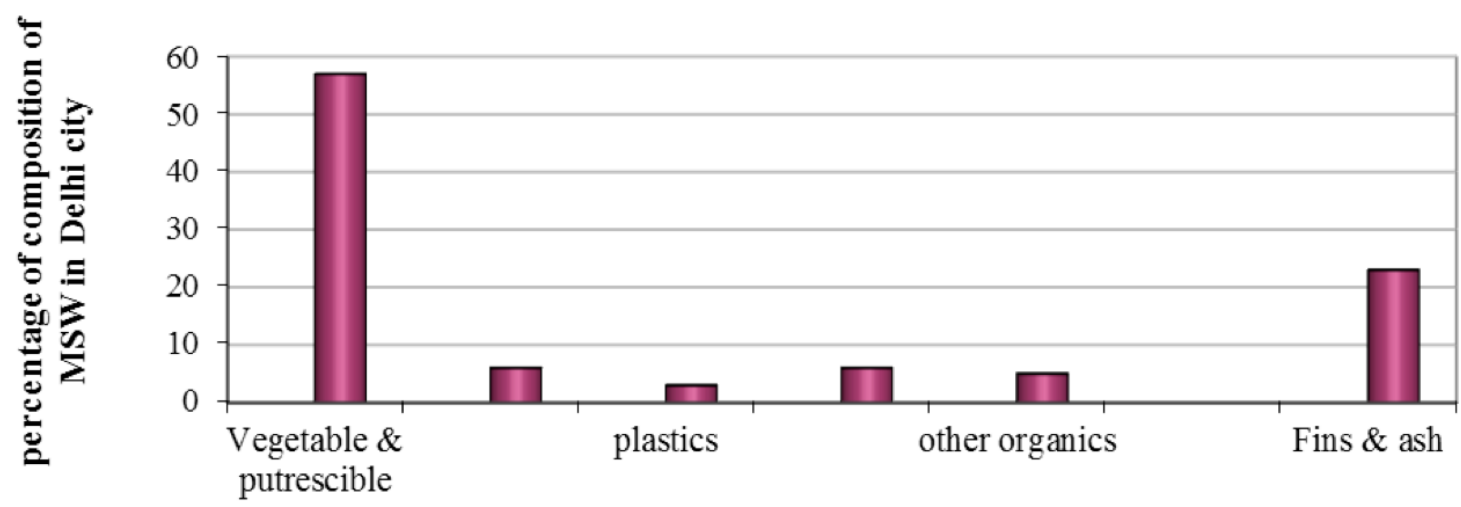

Type of MSW

Figure 5: Percentage of composition of MSW in Delhi city.

purposes. The tar oil can yield some petroleum products when distilled and could be used as fuel and for industrial purposes [46].

\subsection{Industrial Wastewater}

In addition to MSW, large quantity of wastewater is generated in certain industrial plants like breweries, sugar mills, distilleries, food-processing industries, tanneries, and paper and pulp industries. Out of this, food products and agro-based industries together account for $65-70 \%$ of the total industrial wastewater in terms of organic load [47]. Table 5 gives the estimate of wastewater generated in India by industries [48]. Conventional digesters such as anaerobic continuous stirred tank reactors (CSTR) have been used in India for many decades in sewage treatment plants for stabilization of the activated sludge and sewage solids. In recent times, the emphasis has shifted to high-rate biomethanation systems such as up flow Anaerobic Sludge Blanket (UASB), fixed films, etc.

Large amount of wastewater is discharged from various industries under two broad categories: inorganic and organic. Wastewater from organic industries, such as, wood processing, pulp and paper, plastic, soap and synthetic detergent, tanneries and leather, oil refineries, textile, pharmaceutical and cosmetic, etc., are considered in this study. Each industry requires different methods for wastewater treatment depending on the characteristics and amount of wastewater. These methods can be classified as: (i) physical unit processes (screening, mixing, flocculation, sedimentation, flotation, filtration), (ii) chemical unit processes (precipitation, adsorption, disinfection), and (iii) biological unit processes (aerobic processes, anaerobic processes, anoxic denitrification) [49].

\section{CONCLUSION}

Using crop residues as fuel in India still limited compared with the high amount of production, only $48 \%$ from total residue production, and expected to go down in the future, which need further utilization to improve the amount of energy generated. The expected values of dung production indicated that there will be no significant increasing in future. The amount of fuelwood consumed increase with decreasing land 
Table 5: Energy Potential from Wastewater in India

\begin{tabular}{|c|c|c|c|c|}
\hline \multirow{2}{*}{ Industries } & \multirow{2}{*}{$\begin{array}{l}\text { Wastewater produced } \\
\left(\mathrm{Mm}^{3}\right)\end{array}$} & \multirow{2}{*}{$\begin{array}{l}\text { COD* of waste water } \\
\left(\mathrm{kgm}^{-3}\right)\end{array}$} & \multicolumn{2}{|c|}{ Energy value of $\mathrm{CH} 4$ (TJ) } \\
\hline & & & 1997 & 2010 \\
\hline Distillery & 6000 & 118 & 2973.60 & 105138.00 \\
\hline Steel plants & 1040000 & 0.60 & 936.00 & 92664.00 \\
\hline Paper and allied products & 7200 & 0.72 & 7.73 & 765.55 \\
\hline Sugar industry & 230 & 2.30 & 0.79 & 78.56 \\
\hline Cotton & 1550 & 0.60 & 1.40 & 138.11 \\
\hline Fertilizers & 52 & 2.00 & 0.16 & 15.44 \\
\hline Refinery & 15 & 0.30 & 0.01 & 0.67 \\
\hline Dairy & 206 & 1.35 & 0.42 & 41.38 \\
\hline Pharmaceuticals & 56 & 0.39 & 0.03 & 3.24 \\
\hline Coffee & 1.3 & 2.80 & 0.01 & 0.55 \\
\hline Edible oil & 1425 & 4.50 & 9.62 & 952.56 \\
\hline Total & 1056730 & & 3929.77 & 199797.75 \\
\hline
\end{tabular}

*COD: Chemical Oxygen Demand, is widely used in municipal and industrial laboratories to measure the overall level of organic.

forestation which makes this source of energy is limited. The total quantity of solid wastes and wastewater generated in larger towns and cities increased and still in increasing with increase the population, but these sources still not generate sufficient amount of energy to be valuable source for energy. So, further studies need to be done to increase biomass usage as energy source or to maximize the utilization of the existing sources.

\section{REFERENCES}

[1] Cll (Confederation of Indian Industry). Biomass Energy Potential and Prospects - Godrej GBC Publication, RES-Fact Sheet 2004.

[2] Goldemberg J, Johannson TB, Reddy AKN, Williams RH. Energy for a sustainable world. Wiley Eastern Limited, New Delhi, India 1988.

[3] Jackson T. Renewable energy: summary paper for renewable series. Energy Policy 1992; 20: 861-83.

[4] Johansson TB, Kelly $\mathrm{H}$, Reddy AKN, Williams $\mathrm{RH}$. Renewable energy. Island Press, Washington 1993.

[5] Kumar E. Meeting Future Energy Needs: The Indian Perspective, Seminar, Presentation at Energy Monitoring Panel, India 2004.

[6] Ershad AM. Energy consumption pattern in rural Bangladesh - the opportunity for New Zealand: a household survey. Discussion Paper 0210, 2002; ISSN1174-2542.

[7] Ravindranath $\mathrm{NH}$, Hall DO. Biomass, energy and environment a developing country perspective from India. Oxford: Oxford University Press. USA 1995.

[8] Chauhan S. Biomass resources assessment for power generation: A case study from Haryana state, India. Biomass Bioenergy 2010; 34: 1300-308.

http://dx.doi.org/10.1016/j.biombioe.2010.04.003

[9] IEA (International Energy Agency). World Energy Outlook. IEA, Paris 1998.
[10] Karekezi S. Poverty and energy in Africa: impact on the poor. Energy Policy 2002; 30 (11-12): 915-19. http://dx.doi.org/10.1016/S0301-4215(02)00047-2

[11] Goldemberg J, Coelho ST. Renewable energy - traditional biomass vs. modern biomass. Energy Policy 2003; 32(6): 711-14. http://dx.doi.org/10.1016/S0301-4215(02)00340-3

[12] Reddy KN, Williamsand $\mathrm{RH}$, Johansson TB. Energy after Rio: Prospects and challenges. United Nations Development Programme, New York 1997.

[13] Yamamoto H, Yamaji K, Fujino J. Bioenergy in Global Energy Systems in the Future - Considering Land Use Competitions and Energy Resource Constraints, paper presented at the IAEE 21ST Annual International Conference, May 13-16. Quebec City, Canada 1998.

[14] Hall DO, Scrase Jl. Will Biomass be the Environmentally Friendly Fuel of the Future? Biomass Bioenergy 1998; 15(5): 357-67. http://dx.doi.org/10.1016/S0961-9534(98)00030-0

[15] Sims R. Climate Change Solutions From Biomass, Bioenergy and Biomaterials. Agricultural Engineering International: the CIGR Journal of Scientific Research and Development. Invited Overview, Vol. V. September 2003. http://www. cigrjournal.org/index.php/Ejounral/article/view/469/462

[16] Sokhansanj S, Cushman J, Wright L. Collection and Delivery of Feedstock Biomass for Fuel and Power Production. Agricultural Engineering International: the CIGR Journal of Scientific Research and Development, Invited Overview Paper Vol. V, 2003.

[17] Hall DO, Mao YS. Biomass and Coal in Africa. Zed Books Ltd, London 1994.

[18] Karekezi S, Ranja T. Renewable Energy Technologies in Africa. Zed Books, London 1997.

[19] Masera OR, Saatkamp, BD, Kammen DM. Energy and health transactions in development: fuel use, stove technology, and morbidity in Jaracuaro, Mexico. Energy for sustainable Development. No 2:7-16. International Energy Initiate, India 2000.

[20] IPCC (Intergovernmental Panel on Climate Change). Environmental Knowledge for Change 2003; Available at GRID-Arendal; http://www.grida.no/climate 
[21] Coelho ST, Walter AS. Indigenous Technologies for Sustainable Development: Chapter 4. Brazil-Country study for sustainable development. Study funded by the IAEA 2003.

[22] Fisher G, Schrattenholzer L. Global bioenergy potentials through. Biomass Bioenergy 2001; 20(3): 151-59. http://dx.doi.org/10.1016/S0961-9534(00)00074-X

[23] FAO (Food and Agriculture Organization). FAO report, United Nations, Rome 2000.

[24] RWEDP (Regional Wood Energy Development Programme). Regional study on wood energy today and tomorrow in Asia. Bangkok 1997.

[25] WRI (World Resources Institute). Report, 2006; Washington DC. Available at: http://www.wri.org

[26] World Bank. India total population. The World Bank 2013; Available at: http://data.worldbank.org/indicator/SP.POP. TOTL

[27] Ninth Year Plan. Indian Planning Commission: Ninth Year Plan (1997-2002). Government of India 1997; http://www.nic.in

[28] PIB (Press Information Bureau). Indian Agriculture: Performance and Challenges, chapter 1. Press information bureau. Shastri Bhawan, New Delhi 1100012012.

[29] MoEF (Ministry of Environment and Forests). National Forestry Action Programme-India, New Delhi: Ministry of Environment and Forests, Government of India 1999.

[30] CMIE (Centre for Monitoring Indian Economy). Directory of Indian agriculture, Mumbai, India 1997.

[31] Pathak BS, Jain AK, Singh A. Characteristics of crop residues. Agricultural wastes, UK 1986; 16: 27-35.

[32] Baruah DC, Jain AK. Distribution of agriculture crop residues in India. J Agric Eng 1998; 35(1): 7-12.

[33] CES (Centre for Ecological Sciences). Annual Report. Indian Institute of Science, Bangalore, India 1995.

[34] Jekayinfa S, Omisakin O. The Energy Potentials of some Agricultural Wastes as Local Fuel Materials in Nigeria. Agricultural Engineering International: the CIGR Ejournal 2005; Vol. VII. Manuscript EE 05 003: http://www.cigrjournal. org/index.php/Ejounral/article/view/570/564

[35] M.S Swaminathan Research Foundation. Bioenergy Resource Status in India. Working Paper, Prepared for DFID by the PISCES RPC Consortium. M.S Swaminathan Research Foundation. Chennai, India 2011; pp. 1-16.

[36] Anonymous. Housing and amenities: a database on housing and amenities for districts, cities and towns. Occasional Paper, Demography, training and data dissemination division, Census of India, Office of the registrars general and census commissioners, New Delhi, India 1995.

[37] Anonymous. Basic animal husbandry statistics. New Delhi: Government of India 1997.
[38] MNES (Ministry of Non-Conventional Energy Sources). Annual report, ministry of non-conventional energy sources. New Delhi: Govt. of India 1998.

[39] MNRE (Ministry of New and Renewable Energy). Biogas bottling in India: a case study, Ministry of New and Renewable Energy, New Delhi-110 003, India 2011.

[40] NSSO (National Sample Survey office). Energy Used by Indian Households. Report No. 530. New Delhi: Department of Statistics 2008.

[41] Dutt GS, Ravindranath NH, Johansson IN, Kelly H, Reddy AKN, Williams RH. Renewable energy: sources for fuels and electricity. Island Press 1993; 653-98.

[42] Chukla PR. Biomass energy strategies for aligning development and climate goals in India. Presented on workshop of rural development and role of food, water and biomass opportunities for development and climate, Dakkar 2005.

[43] Malik DP, Dhanda S. Status, Trends and Demand for Forest Products in India, 2003. Available at: http://www.fao.org/ docrep/article/wfc/xii/0228-b1.htm

[44] Asian Productivity Organization. Green Productivity Approaches to SWM: Turning Waste into Profit. Report of the APO Survey on Solid-Waste Management 2004-05. Solid Waste Management: Issues and Challenges in Asia. Edited by the Environmental Management Centre, Mumbai, India. Asian Productivity Organization, Tokyo 102-0093, Japan 2005.

[45] Bhattacharya SC, Abdul-Salama $P$, Runqing HU, Somashekar HI, Racelis DA, Rathnasiri PG, Yingyuad R. An assessment of the potential for non-plantation biomass resources in selected Asian countries for 2010. Biomass Bioenergy 2005; 29: 153-66. http://dx.doi.org/10.1016/j.biombioe.2005.03.004

[46] Ojolo S, Bamgboye A. Thermochemical Conversion of Municipal Solid Waste to Produce Fuel and Reduce Waste. Agricultural Engineering International: the CIGR Ejournal 2005; Vol. VII. Manuscript EE 05 006. http://www.cigrjournal. org/index.php/Ejounral/article/view/582/576

[47] Pachauri RK, Sridharan PV. Solid wastes. In looking back to think ahead. New Delhi: Tata Energy Research Institute 1998; 245-65.

[48] Hammer MJ, Hammer MK. Wastewater flows and characteristics: In water and wastewater technology. New Delhi: Prentice-Hall of India Pvt Ltd 1998; p. 515.

[49] Bhattacharya SC, Abdul-Salama P, Phama HL, Ravindranathb $\mathrm{NH}$. Sustainable biomass production for energy in selected Asian countries. Biomass Bioenergy 2003; 25: 471-82.

http://dx.doi.org/10.1016/S0961-9534(03)00085-0 